ГІАРОГЕОАОГІЧНИЙ МОНТТОРИНГ І МАТЕМАТИЧНЕ МОАЕАЮВАННЯ РААІОАКТИВНОГО ЗАБРУАНЕННЯ ПІАЗЕМНИХ ВОА У ЧОРНОБИАЬСЬКІЙ ЗОНІ ВІАЧУЖЕННЯ I НА УРАНОВИХ ОБ' ЄКТАХ КОАИШНЬОГО ПРИАНІПРОВСЬКОГО XIMIЧНОГО ЗАВОАУ (м. Камянське)

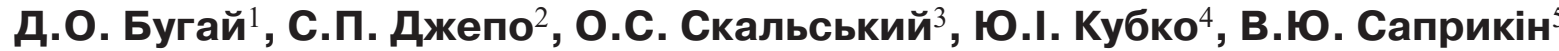 \\ ${ }^{1}$ Iнститут геологічних наук НАН Украӥни, Київ, Україна, E-mail: dmitri.bugai@igs-nas.org.ua \\ Кандидат фізико-математичних наук, старший науковий співробітник. \\ ${ }^{2}$ Iнститут геологічних наук НАН України, Київ, Україна, E-mail: dzhepoSP1947@nas.gov.ua \\ Кандидат геолого-мінералогічних наук, старший науковий співробітник. \\ ${ }^{3}$ Інститут геологічних наук НАН України, Київ, Україна, E-mail: askals@online.ua \\ Кандидат геолого-мінералогічних наук, старший науковий співробітник. \\ ${ }^{4}$ Інститут геологічних наук НАН України, Київ, Україна, E-mail: yury.kubko@gmail.com \\ Молодший науковий співробітник. \\ ${ }^{5}$ Інститут геологічних наук НАН Украӥни, Київ, Україна, E-mail: vladimirsaprykin@ukr.net \\ Провідний гідрогеолог.
}

Представлено огляд досліджень із проблеми моніторингу радіоактивного забруднення підземних вод і прогнозування геоміграційних процесів. Надано оцінку відповідних ризиків для людини й оточуючого середовища. Розроблено стратегії і заходи щодо захисту водних ресурсів. Зазначені дослідження були виконані в Інституті геологічних наук НАН України протягом 1995-2017рр. для радіаційно-небезпечних об'єктів Чорнобильської зони відчуження та уранових об’єктів колишнього Виробничого об’єднання «Придніпровський хімічний завод» (м. Кам'янське).

Ключові слова: гідрогеологічний моніторинг; математичне моделювання; оцінки ризику; природоохоронні заходи.

\title{
GROUNDWATER MONITORING AND MATHEMAICAL MODELING OF RADIOACTIVE CONTAMINATION OF GROUNDWATER IN CHERNOBYL EXCLUSION ZONE AND FOR THE URANIUM FACILITIES OF THE FORMER PRIDNEPROVSKY CHEMICAL PLANT (Kamyanske)
}

\section{D.O. Bugai ${ }^{1}$, S.P. Dzhepo' ${ }^{2}$, O.S. Skalskyy ${ }^{3}$, Yu.I. Kubko ${ }^{4}$, V.Yu. Saprykin ${ }^{5}$}

${ }^{1}$ Institute of Geological Sciences of NAS of Ukraine, Kyiv, Ukraine, E-mail: dmitri.bugay@gmail.com Candidate of physical-mathematical sciences, senior researcher.

${ }^{2}$ Institute of Geological Sciences of NAS of Ukraine, Kyiv, Ukraine, E-mail: dzhepoSP1947@nas.gov.ua Candidate of geological-mineralogical sciences, senior researcher.

${ }^{3}$ Institute of Geological Sciences of NAS of Ukraine, Kyiv, Ukraine, E-mail: askals@online.ua Candidate of geological-mineralogical sciences, senior researcher.

${ }^{4}$ Institute of Geological Sciences of NAS of Ukraine, Kyiv, Ukraine, E-mail: yury.kubko@gmail.com Junior researcher.

${ }^{5}$ Institute of Geological Sciences of NAS of Ukraine, Kyiv, Ukraine, E-mail: vladimirsaprykin@ukr.net Leading hydrogeologyst.

The review of researches on the problem of monitoring of radioactive contamination of groundwater and forecasting of geomagnetic processes is presented. The assessment of the appropriate risks for humans and the environment is given. Strategies and measures for the protection of water resources have been developed. These studies were performed at the Institute of Geological Sciences of the NAS of Ukraine during 1995-2017 for radiation hazardous objects of the Chornobyl Exclusion Zone and uranium facilities of the former Production Association «Pridneprovsky Chemical Plant» (Kamyants'ke).

Key words: groundwater monitoring; mathematical modeling; risk assessment; remedial measures.

( Д.О. Бугай, С.П. Джепо, О.С. Скальський, Ю.І. Кубко, В.Ю. Саприкін, 2018 


\title{
ГИАРОГЕОАОГИЧЕСКИЙ МОНИТОРИНГ И МАТЕМАТИЧЕСКОЕ МОАЕАИРОВАНИЕ РААИОАКТИВНОГО ЗАГРЯЗНЕНИЯ ПОАЗЕМНЫХ ВОА В ЧЕРНОБЫАЬСКОЙ ЗОНЕ ОТЧУЖАЕНИЯ И НА УРАНОВЫХ ОБЪЕКТАХ БЫВШЕГО ПРИАНЕПРОВСКОГО ХИМИЧЕСКОГО ЗАВОАА (г. КаменСКОе)
}

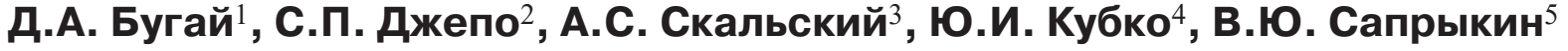

\author{
${ }^{1}$ Институт геологических наук НАН Украины, Киев, Украина, E-mail: dmitri.bugay@gmail.com \\ Кандидат физико-математических наук, старший научный сотрудник. \\ ${ }^{2}$ Институт геологических наук НАН Украины, Киев, Украина, E-mail: dzhepoSP1947@nas.gov.ua \\ Кандидат геолого-минералогических наук, старший научный сотрудник. \\ ${ }^{3}$ Институт геологических наук НАН Украины, Киев, Украина, E-mail: askals@online.ua \\ Кандидат геолого-минералогических наук, старший научный сотрудник. \\ ${ }^{4}$ Институт геологических наук НАН Украины, Киев, Украина, E-mail yury.kubko@gmail.com \\ Младиий научнытй сотрудник. \\ ${ }^{5}$ Институт геологических наук НАН Украины, Киев, Украина, E-mail vladimirsaprykin@ukr.net \\ Ведущий гидрогеолог.
}

Представлен обзор исследований проблемы мониторинга радиоактивного загрязнения подземных вод, прогнозирования геомиграционных процессов. Дана оценка соответствующих рисков для человека и окружающей среды. Разработаны стратегии и мероприятия по защите водных ресурсов. Указанные исследования выполнены в Институте геологических наук НАН Украины в течение 1995-2017 гг. для радиационно-опасных объектов Чернобыльской зоны отчуждения и урановых объектов бывшего ПО «Приднепровский химический завод» (г. Каменское).

Ключевые слова: гидрогеологический мониторинг; математическое моделирование; оценки риска; природоохранные мероприятия.

\section{Ветуп}

Представлено огляд і основні результати гідрогеологічних досліджень, що були виконані в відділі моніторингу геологічного середовища (ВМГС) Інституту геологічних наук (ІГН) НАН України в роки незалежності і до теперішнього часу. Основні напрями досліджень ВМГС починаючи від створення відділу в 1995 р. були зосереджені на вивченні радіоактивного забруднення підземних вод внаслідок Чорнобильської катастрофи, моніторингу грунтів зони аерації і підземних вод, прогнозуванні геоміграційних процесів, оцінці ризиків для людини й оточуючого середовища та на розробці стратегій і заходів щодо захисту водних ресурсів. Оскільки проблеми радіоактивного забруднення підземних вод $є$ найбільш гострими в Чорнобильській зоні відчуження (ЧЗВ), дослідження були зосереджені на об'єктах ЧЗВ, а саме: ставі-охолоджувачі ЧАЕС, об'єкті «Укриття», пунктах поховання радіоактивних відходів (РАВ) та ін. У зазначений період дослідження виконували під керівництвом завідуючого відділом канд. геол.-мінерал. наук С.П. Джепо. Починаючи з 2005 р. спеціалісти відділу застосували досвід, здобутий в Чорнобилі для аналогічних досліджень на іншому радіаційно-небезпечному об'єкті - на хвостосховищах та інших об'єктах інфраструктури колишнього Виробничого об'єднання «Придніпровський хімічний завод» (ПХЗ) (м. Кам'янське), що в радянський період був ключовим підприємством колишнього СРСР із переробки уранових руд; причому об'єкти цього підприємства не були належним безпечним чином виведені із експлуатації після розпаду СРСР в 1991 p. і припинення функціонування підприємства. В 2016 р. ВМГС було об'єднано з відділом інженерної геології ІГН НАН України, і дослідження із зазначеної тематики продовжуються групою співробітників, що входить до однойменної 3 колишнім відділом лабораторії (автори статті), в складі вже нового відділу. Вказані роботи проводилися в рамках бюджетних тем ІГН НАН України, госпдоговірної тематики і міжнародних науково-дослідних проектів (грантів).

\section{Моніторинг і моделювання підземних вод з метою оперативної оцінки ситуації i обгрунтування водоохоронних заходів у ЧЗВ На початковому етапі ліквідації наслідків аварії на ЧАЕС гостро постали питання створення системи моніторингу підземних вод у ЧЗВ, опе- ративної оцінки і прогнозування процесів радіо-}



у Чорнобильській зоні відчуження і на уранових обєєктах колишнього Придніпровського хімічного заводу (м. Кам'янське)

активного забруднення підземних вод. Для вирішення вказаних задач вченими ВМГС було виконано великий обсяг польових гідрогеологічних досліджень в ЧЗВ. У результаті цього в 10-кілометровій зоні ЧАЕС в 1995 р. було побудовано розгалужену мережу гідрогеологічних свердловин малого діаметра для дослідження радіоактивного забруднення першого від поверхні безнапірного водоносного горизонту в четвертинних відкладах (понад 100 свердловин). На основі цієї мережі свердловин було складено перші детальні кондиційні карти радіоактивного забруднення підземних вод у центральній частині ЧЗВ [Джепо та ін., 1996].

Одночасно науковцями ВГМС проведено роботи із створення регіональної гідрогеологічної (фільтраційної) цифрової моделі ЧЗВ на ос- нові програми MODFLOW. Модель охоплює межиріччя Прип'яті, Ужа, Іллі та Сахану, що є іiі гідрогеологічними границями (рис. 1). Модель складається 3 двох водоносних горизонтів: безнапірного в четвертинних відкладах і напірного в еоценових піщаних відкладах. Опис моделі наведено в роботі [Скальський та Кубко, 2000]. В подальші роки модель було використано для багатьох прикладних гідрогеологічних прогнозів і досліджень в ЧЗВ.

Застосування зазначеної моделі дозволило оцінити напрямки і швидкості фільтрації підземних вод та відповідні міграційні потоки радіонуклідів від радіаційно-небезпечних об'єктів у ЧЗВ, виконати перші оцінки ризиків радіоактивного забруднення підземних вод [Bugai et al., 1996a, b].

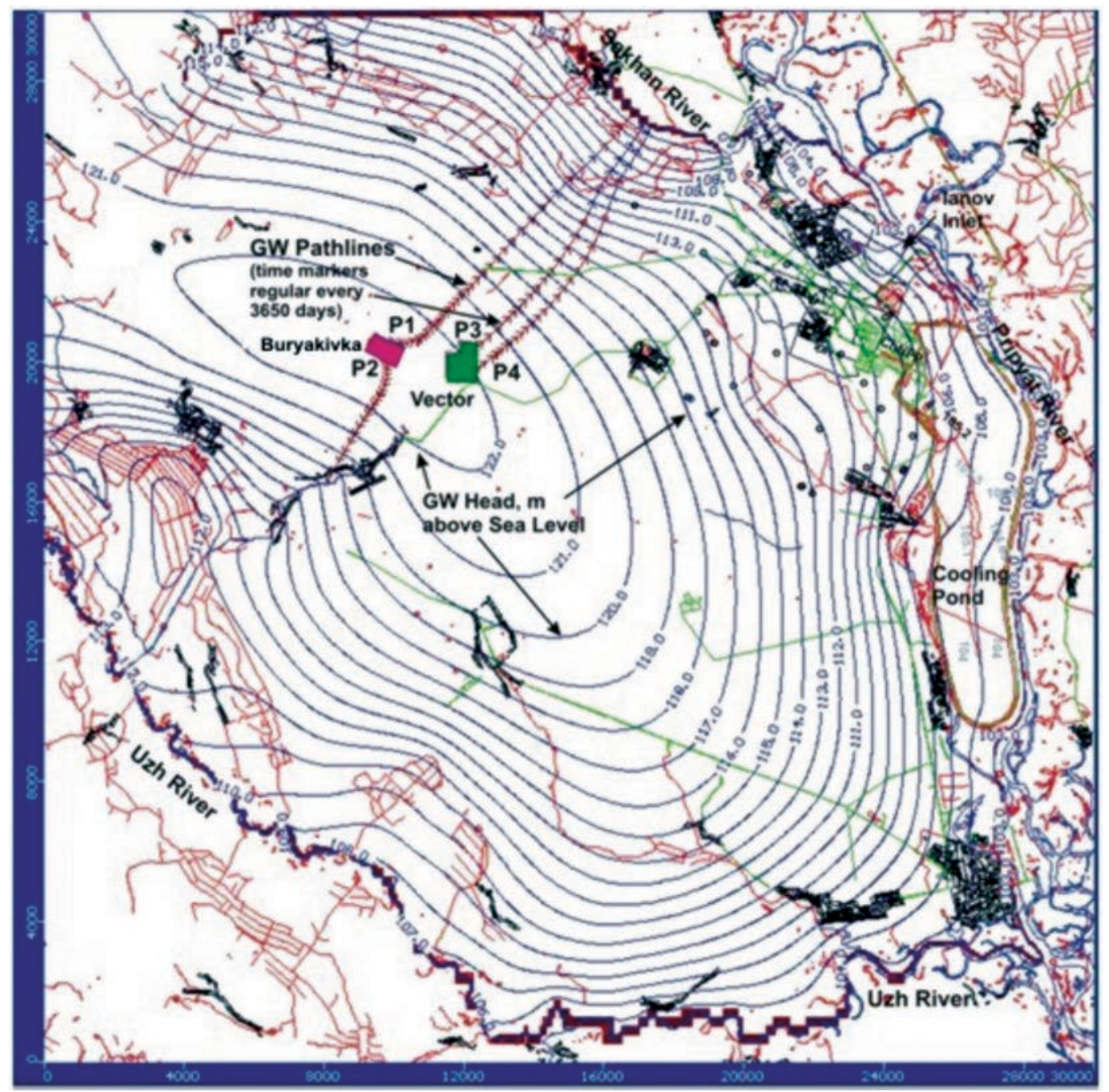

Рис. 1. Регіональна фільтраційна модель Чорнобильської зони відчуження. Результати моделювання показують ізолінії напорів і лінії току в безнапірному водоносному горизонті від ПЗРВ «Буряківка» і ділянки комплексу для поводження з РАВ «Вектор»

Fig. 1. Regional groundwater flow model of Chernobyl Exclusion zone. Simulation results show hydraulic head isolines and flow lines distribution in the unconfined aquifer from "Buryakivka" and "Vector" radioactive waste disposal sites 
На основі проведених польових досліджень, математичного моделювання фільтраційних процесів і аналізу міжнародного досвіду було надано рекомендації моніторинговим службам ЧЗВ (на сьогоднішній день це ДСП «Екоцентр») щодо облаштування стаціонарної мережі спостережних свердловин, регламенту спостережень і методики відбору зразків підземної води для аналітичних досліджень [Джепо та ін., 1996].

Також було виконано комплекс досліджень з типізації геологічної будови і гідрогеологічних умов зони ЧАЕС 3 позицій схематизації умов міграції радіонуклідів аварійного викиду ЧАЕС [Matoshko et al., 2004].

Спеціалісти ІГН НАН України разом з іншими інститутами НАН України і галузевими інститутами взяли участь у розробці технікоекономічного обгрунтування (ТЕО) «Схеми водоохоронних заходів...» для захисту від радіоактивного забруднення поверхневих і підземних вод у ЧЗВ. Результатом цих робіт стало спорудження Лівобережної захисної дамби (1993р.) і Правобережної захисної дамби (1998р.) на p. Прип'ять в 10-кілометровій зоні ЧАЕС, що ізолювало річкову мережу від найбільш небезпечних джерел радіоактивного забруднення [Шестопалов та ін., 2006].

Результати описаних вище досліджень підсумовані в розділах монографій [Dzhepo and Skalskyy, 2002; Bugai et al., 2007].

\section{Полігонні дослідження геоміграційних процесів радіонуклідів у чорнобильському «Рудому лісі»}

В 1999-2015 pp. 3 ініціативи науковців ВМГС і на основі попередніх моніторингових робіт в ЧЗВ ІГН НАН України у співпраці із Українським НДІ сільськогосподарської радіології (УкрНДІСГР) і за фінансової підтримки Інституту радіаційного захисту і ядерної безпеки (IRSN, Франція) була реалізована серія міжнародних радіоекологічних науково-дослідних проектів - «Чорнобильський пілотний майданчик» (Chernobyl Pilot Site Project, 1999-2003) i «Міжнародна платформа в Чорнобилі» (“Ехреrimental Platform in Chernobyl”, 2004-2015) [Dewiere et al., 2004; Van Meir et al., 2009]. Проекти мали на меті дослідження міграції радіонуклідів із приповерхневого поховання РАВ, що вміщує частинки диспергованого ядерного палива 4-го блоку ЧАЕС (паливні частинки), побудову i експериментальну валідацію (підтвердження) відповідних математичних моделей міграції радіоактивних речовин. Для цього в ближній зоні ЧАЕС на ділянці пункту тимчасової локалізації радіоактивних відходів (ПТЛРВ) «Рудий ліс» поблизу траншеї № 22-Т в 1999-2000рр. було організовано експериментальний майданчик, обладнаний сучасними автоматизованими системами гідрогеологічних і гідрометеорологічних спостережень (рис. 2). Основну увагу було приділено вивченню міграції стронцію-90, що вирізнявся найбільш високою мобільністю в геологічному середовищі.

Дослідження за зазначеними проектами дозволили одержати унікальний за детальністю набір моніторингових даних про міграцію радіонуклідів із поховання РАВ у грунтах зони аерації, підземних водах і в рослинності експериментальної ділянки. Польові дослідження та експерименти були доповнені програмою спеціальних лабораторних радіохімічних і гідрофізичних досліджень. В результаті було одержано комплексну і детальну інформацію про міграційну поведінку паливних частинок в похованні РАВ, а також про міграційні потоки (гідрологічні, біотичні) і параметри міграції радіонуклідів у досліджуваній природно-техногенній екосистемі «Рудого лісу». На заключній стадії проекту було побудовано і відкалібровано (параметризовано) математичні моделі, що описують процеси трансформації (розчинення) паливних частинок у похованні, а також 2- і 3-вимірні математичні моделі міграції стронцію-90 в системі «поховання РАВ - зона аерації - водоносний горизонт» [Саприкін та ін., 2011; Bugai et al., 2012а]. На заключній стадії проекту було виконано комплекс робіт із ізотопного датування підземних вод і вивчення автореабілітаційних геохімічних процесів у досліджуваній природнотехногенній екосистемі поховань РАВ чорнобильського «Рудого лісу» [Бугай та ін., 2010; Bugai et al., 2012b].

База даних і радіоекологічні моделі, створені в рамках зазначених проектів, знайшли застосування в численних прикладних дослідженнях в ЧЗВ; наприклад, при розробці стратегії поводження з РАВ, зосереджених в пунктах захоронення і локалізації відходів у ближній зоні ЧАЕС [Antropov et al., 2001]. Експериментальний майданчик біля траншеї № 22-Т наразі також використовується як навчальна база в міжнародних освітніх проектах у галузі радіоекології. 
Гідрогеологічний моніторинг і математичне моделювання радіоактивного забруднення підземних вод у Чорнобильській зоні відчуження і на уранових об’єктах колишнього Придніпровського хімічного заводу (м. Кам'янське)

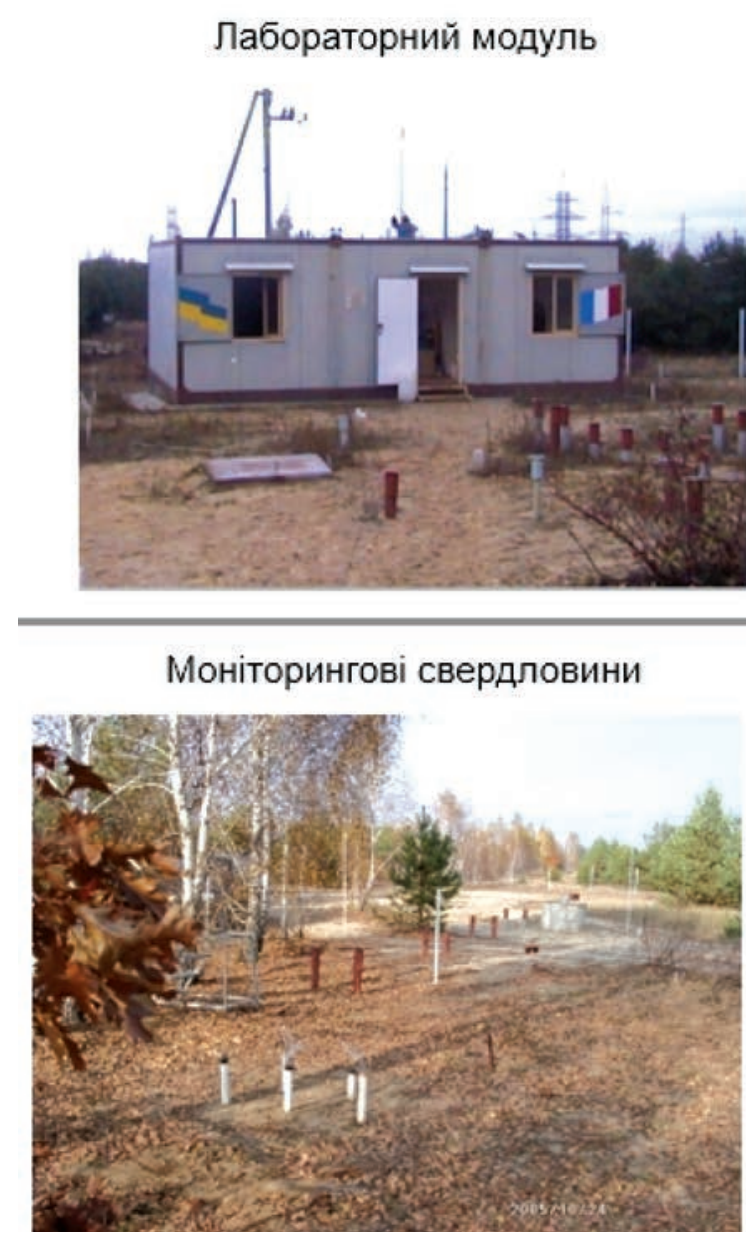

Шурф для моніторингу зони аерації

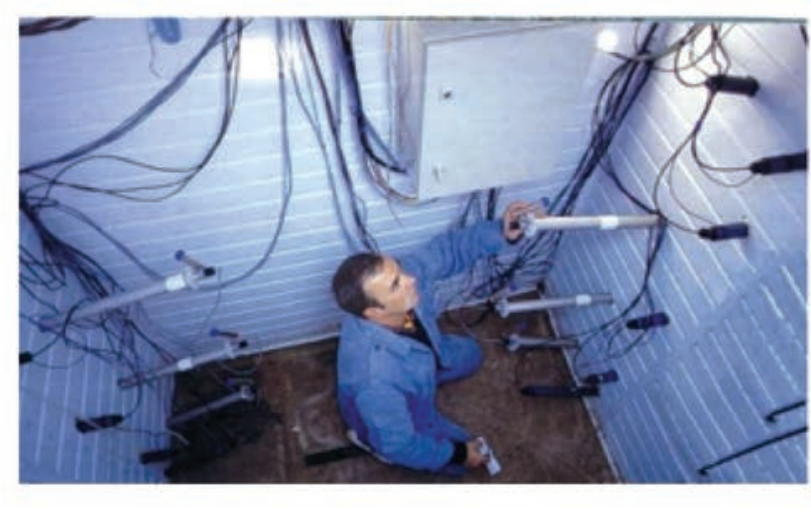

Метеостанція

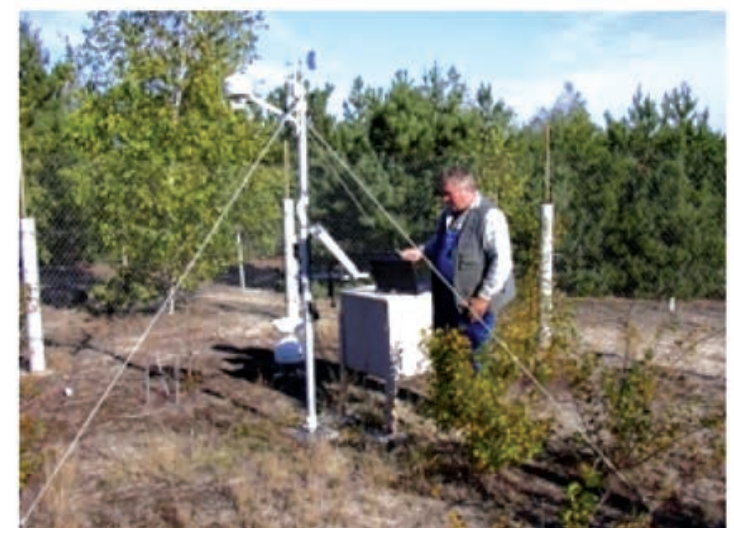

Рис. 2. Дослідна інфраструктура полігону біля траншеї № 22-Т пТЛРВ «Рудий ліс» в 10-кілометровій зоні ЧАЕС (фото 2004 р.)

Fig. 2. Research equipment infrastructure of the experimental site near trench no. 22-T of "Red Forest" waste dump site in the 10-km zone of Chernobyl NPP (photo from 2004)

Дослідження міграції радіонуклідів на малому експериментальному водозборі «Борщі» в ЧЗВ

В 1998-2002 рр. вчені ВМГС ІГН НАН України у співпраці із Університетом Британської Колумбії (Ванкувер, Канада) виконали програму польових полігонних досліджень з моніторингу і комплексного вивчення процесів водної міграції стронцію-90 в натурних умовах спеціально обладнаного малого експериментального водозбору (приблизно 8,5 км²) в урочищі Борщі в ближній 10-кілометровій зоні ЧАЕС (що належить до меліоративної системи «Копачі»). Залучення сучасних інструментальних засобів для моніторингу гідрологічних процесів та комплексний характер досліджень (з урахуванням гідрологічних, гідрогеологічних, геохімічних аспектів) дозволили виконати детальний аналіз механізмів гідрологічної міграції стронцію-90 в межах водозбору і визначити основні джерела надходження радіонукліду в поверхневі води. Особливу увагу було приділено вивченню процесів масообміну між водною колонкою і донними відкладами, а також вилуговуванню радіонуклідів із болотних відкладів і сезонно-підтоплених грунтів, котрі, як виявили дослідження, відіграють ключову роль в міграції радіонуклідів до поверхневих вод [Freed et al., 2004]. Результати зазначених досліджень мали велике значення для обгрунтування стратегії поводження з меліоративними системами і малими річками Зони відчуження [Шестопалов та ін., 2006].

\section{Обгрунтування стратегії зняття}

з експлуатації ставка-охолоджувача ЧАЕС

Науковці ІГН НАН України зробили вагомий внесок в обгрунтування стратегії поводження зі ставком-охолоджувачем Чорнобильської АЕС, що зазнав значного радіоактивного забруднення при Чорнобильській аварії і перетворився 
внаслідок фільтраційного виносу радіоактивності на одне із найбільш суттєвих джерел забруднення р. Прип’ять стронцієм-90. Дослідження включали польові експериментальні роботи 3 визначення водного балансу водойми, фільтраційних параметрів дамби, оцінки дійсних швидкостей фільтрації підземних вод, сорбційних властивостей грунтів дамби та ін. Було створено комплекс цифрових фільтраційних i геоміграційних моделей ставка-охолоджувача із використанням програм MODFLOW, MT3D i Ecolego. Це дозволило виконати гідрогеологічні прогнози осушення водойми в рамках ТЕО стратегії зняття з експлуатації цього складного радіаційно-небезпечного природно-техногенного об'єкта [Бугай та ін., 2005]. Відповідні гідрогеологічні прогнози динаміки осушення водойми i виносу радіонуклідів при різних граничних умовах (метеорологічних, гідрологічних) були використані при оцінці впливів ставка-охолоджувача на оточуюче середовище і розробці реабілітаційних заходів щодо радіоактивно-забруднених донних відкладів водойми. Проектні розрахунки були підтверджені в ході фактичного зняття 3 експлуатації водойми-охолоджувача, що розпочалося в 2014 р. і продовжується на цей момент.

\section{Оцінки безпеки пунктів локалізації і захоронення РАВ у ЧЗВ}

До гострих радіоекологічних проблем, пов'язаних з ліквідацією наслідків аварії на ЧАЕС, належить поводження з великими обсягами РАВ (забруднений грунт, будівельні матеріали, біологічні відходи тощо), що утворилися внаслідок катастрофи. Ці РАВ зосереджені як в інженерних сховищах (так званих пунктах захоронення РАВ - ПЗРВ «Буряківка», «Підлісний», «3-я черга ЧАЕС»), так і в ПТЛРВ, що являють собою траншеї (або «бурти») в місцевих грунтах, де були складовані РАВ без кондиціювання, без контейнеризації i, загалом, без належної ізоляції від оточуючого середовища. Міграція 3 підземними водами є основним шляхом міграції радіонуклідів і потенційного опромінення населення для подібних об'єктів, що зумовлює актуальність моніторингових досліджень і гідрогеологічних прогнозів.

У післяаварійний період вченими ВМГС ІГН НАН України було розроблено математичні моделі, виконано гідрогеологічні прогнози та одержано оцінки радіаційних ризиків майже для всіх перелічених основних сховищ РАВ у ЧЗВ, включаючи ПТЛРВ і ПЗРВ [Bugai et al., 1996а; Bugai et al., 2007; Bugai et al., 2012a]. Вказані дослідження були враховані при розробці стратегії поводження з цими об'єктами і при пріоритезації заходів щодо вилучення і безпечного перепоховання РАВ $з$ дотриманням належних вимог радіаційної безпеки [Antropov et al., 2001; Molitor et al., 2017]. В останні роки виконано комплекс робіт з математичного моделювання приповерхневих сховищ РАВ у рамках обгрунтування безпеки створення нових інженерних сховищ відходів на комплексі по поводженню 3 РАВ «Вектор» у ЧЗВ [Bugai et al., 2017] і у зв'язку з розширенням ПЗРВ «Буряківка» (рис. 1).

Дослідження з моніторингу та оцінки безпеки уранових об'сктів колишнього Придніпровського хімічного заводу (м. Кам'янське)

Починаючи із 2005 р. спеціалісти ВМГС брали активну участь в гідрогеологічних дослідженнях ще одного радіаційно-небезпечного об'єкта колишнього ВО «Придніпровський хімічний завод» (ПХЗ), розташованого на околиці м. Кам'янське. Це підприємство було одним із найбільших центрів переробки уранових руд для ядерної програми колишнього СРСР, але після розпаду Радянського Союзу в 1991 р. не було належним безпечним чином виведено із експлуатації. Зокрема, до небезпечних об'єктів ПХЗ належать численні хвостосховища переробки уранових руд («Дніпровське», «Західне», «Центральний Яр», «Південно-Східне», «Сухачівське» секція-I і II), що є джерелами забруднення підземних вод радіонуклідами уран-торієвого ряду і хімічними токсикантами та являють собою загрозу забруднення розташованих поряд річок Коноплянка і Дніпро.

Вченими ІГН було надано методичну і технічну допомогу підприємству ДП «Бар'єр», що виконує реабілітаційні роботи на об'єктах ПХЗ, налагоджено гідрогеологічний моніторинг, виконано дослідно-фільтраційні роботи із визначення геофільтраційних параметрів геологічного середовища в зоні впливу хвостосховищ. Для промислового майданчика ПХЗ і для «Сухачівського майданчика» (де розташовані однойменне хвостосховище і майданчик для зберігання уранової руди «База С») було створено комплекс геостатистичних і гідрогеологічних цифрових моделей на основі програми MODFLOW (рис. 3). Із використанням зазначених фільтраційних моделей і геоміграційних моделей на основі програми 
Гідрогеологічний моніторинг і математичне моделювання радіоактивного забруднення підземних вод у Чорнобильській зоні відчуження і на уранових обєктах колишнього Придніпровського хімічного заводу (м. Кам'янське)

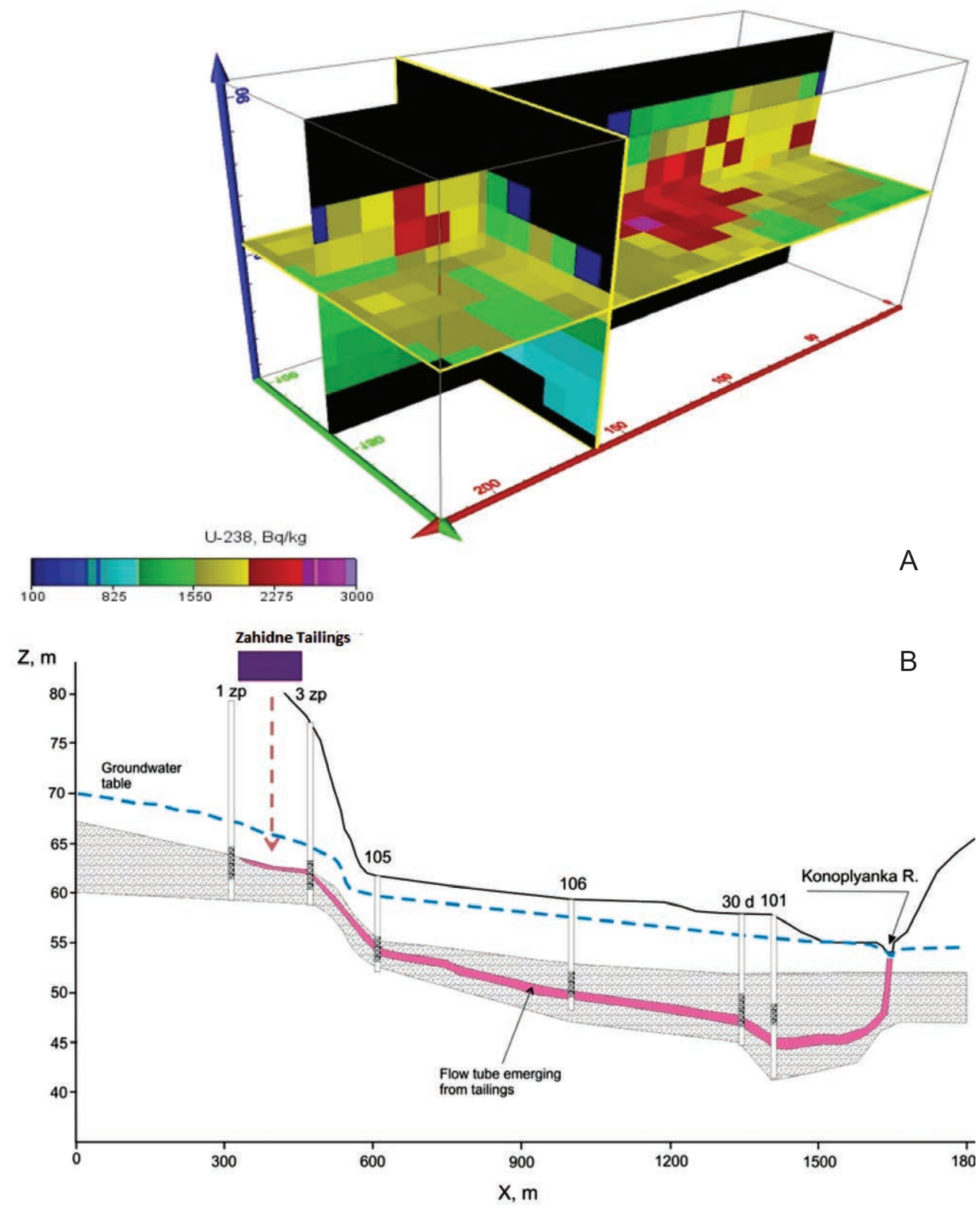

Рис. 3. Чисельні моделі для уранового хвостосховища «Західне» Придніпровського хімічного заводу: (А) Геостатистична модель розподілу урану в тілі хвостосховища; (В) Профільна модель процесів фільтрації і масопереносу в системі хвостосховище «Західне» - р. Коноплянка

Fig. 3. Numerical models for uranium mill tailings site "Zahidne" of Pridneprovsky Chemical Plant: (A) Geostatistical model of uranium distribution in the body of tailings; (B) Cross-sectional model for groundwater flow radionuclide transport in the system "Zahidne" Tailings - Konoplyanka River 
Ecolego було виконано гідрогеологічні прогнози для хвостосховищ уранових руд ПХЗ. Протягом 2011-2014 pp. у рамках проекту українськошведського науково-технічного співробітництва "ENSURE-II Academic" ІГН НАН України (головна організація) та інші академічні і галузеві інститути (УкрНДГМІ, УкрНДІСГР, ІПММС НАН України) виконали комплексну оцінку безпеки об'єктів ПХЗ і розробили елементи стратегії приведення ПХЗ в екологічнобезпечний стан [Skalskyy et al., 2011; Bugai et al., 2014, 2015].

\section{Підсумки і перспективи}

Накопичений в ІГН НАН України досвід гідрогеологічних досліджень і оцінки ризиків від радіаційно-небезпечних об'єктів у ЧЗВ і на майданчику ПХЗ, висвітлений вище в цій статті, було узагальнено в багатьох науково-технічних публікаціях (понад 100) і в тематичних монографіях, в тому числі численних зарубіжних виданнях (див. список літератури до цієї статті щодо деяких основних публікацій).

У сфері обміну досвідом із зазначеної тематики спеціалісти ВМГС ІГН НАН України активно співпрацюють 3 Міжнародним Агентством з Атомної Енергетики (МАГАТЕ) Зокрема, за участі вчених ІГН НАН України було підготовлено ряд технічних документів МАГАТЕ з рекомендаціями щодо захисту підземних вод від радіоактивного забруднення i застосування математичних моделей для обгрунтування реабілітаційних заходів щодо радіаційно-забруднених об'єктів [IAEA, 1999, in press].

B рамках проекту MAГATE MODARIA (Modelling and Data for Radiological Assessment, 2011-2015) за участі представників ІГН НАН України в Робочій Групі 3-го проекту (NORMоб'єкти) на платформі програми Ecolego 6 було розроблено програмний засіб NORMALYSA (NORM And LegacY Site Assessment) для радіоекологічного моделювання і оцінок ризиків при реабілітації радіоактивно-забруднених об’єктів

\section{Список літератури}

Бугай Д.О., Скальський О.С., Джкепо С.П., Осколков Б.Я. Експериментальні гідрогеологічні дослідження і фільтраційні розрахунки водойми-охолоджувача Чорнобильської АЕС. Бюл. екол. стану Зони відчуження та зони безумовного (обов'язкового) відселення. 2005. № 1 (25). С. 42-56.
[Avila et al., 2018]. Спеціалісти ВМГС зробили внесок у розробку блоку модулів для розрахунків міграції радіонуклідів у підземних водах. В останні роки пакет NORMALYSA знайшов застосування при гідрогеологічних розрахунках $\mathrm{i}$ оцінках безпеки для об'єктів комплексу «Вектор» у ЧЗВ, при реабілітації уранових об'єктів у країнах Центральної Азії, в інших прикладних проектах, а також в учбових цілях.

Дослідження із зазначеної тематики дуже актуальні в Україні і світі, зокрема у зв'язку із переглядом адміністративного статусу і зонування радіоактивно-забруднених територій (ЧЗВ і Зона безумовного (обов' язкового) відселення), що були відчужені і виведені із активного природокористування внаслідок аварії на ЧАЕС. Зазначені питання розглядаються в міжнародному проекті українсько-японського співробітництва за програмою SATREPS (2016-2021), що має поєднати досвід ліквідації ядерних аварій в Чорнобилі і Фукусімі, участь в якому беруть вчені ІГН НАН України.

Крім того, важливим напрямом, що потребує подальших гідрогеологічних досліджень, $€$ розвиток комплексу «Вектор» у ЧЗВ для приповерхневого поховання i довгострокового зберігання РАВ, а також розвиток програми досліджень із створення національного геологічного сховища довгоіснуючих і високоактивних PAB.

Одночасно за підтримки СС у рамках програми технічної допомоги INSC (International Nuclear Safety Cooperation Program) створено «дорожню карту» і розпочато підготовчі роботи для приведення в екологічно-безпечний стан об'єктів ПХЗ.

Науковці ІГН НАН України мають значні напрацювання із зазначеної тематики (що, зокрема, слугувало інформаційним підгрунтям і дозволило розпочати перелічені вище проекти), необхідний досвід і відповідний науковий потенціал для подальшого вирішення нагальних проблемних питань радіаційної та екологічної безпеки в Україні і світі.

Бугай Д.А., Фурре Э., Жан-Баптист П., Дапоньи А., Бомьер Д., Ле Галь Ла Саль К., Ланселот Ж., Скальский А.С., Ван Меер Н. Оценка водообмена подземных вод в ближней зоне ЧАЭС на основе данных изотопного датирования и гидрогеологического моделирования. Геол. журн. 2010. № 4 (333). С. 119-124. 
Гідрогеологічний моніторинг і математичне моделювання радіоактивного забруднення підземних вод у Чорнобильській зоні відчуження і на уранових об’єктах колишнього Придніпровського хімічного заводу (м. Кам'янське)

Дожепо С.П., Скальский А.С., Бугай Д.А. Проблемы мониторинга подземных вод в Зоне отчуждения Чернобыльской АЭС. Геол. журн. 1996. № 1-2 (281). C. 107-112.

Скальский А.С., Кубко Ю.И. Фильтрационные модели района ЧАЭС. Водообмен в гидрогеологических структурах и Чернобьльская катастрофа. T. 2. Моделирование водообмена и миграичи радионуклидов в гидрогеологических структурах. Киев, 2001. C. 462-494.

Саприкін В.Ю., Бугай Д.О., Скальський О.С., Джеспо С.П., Ван Меср Н., Кубко Ю.І., Сімонуччі К. Режим інфільтраційного живлення грунтових вод на ділянці чорнобильського «Рудого лісу». 3б. наук. $п$ р. Ін-ту геол. наук НАН Украӥни. 2011. Вип. 4. С. 141-151.

Шестопалов В.М., Шевченко О.Л., Бугай Д.О., Кірєєв С.I., Насвіт O.I., Проскура М.I. Перспективи водоохоронної діяльності в Чорнобильській Зоні відчуження. Бюл. екол. стану Зони відчуження та зони безумовного (обов 'язкового) відселення. 2006. № 1 (27). C. $62-73$.

Avila R., Johansson E., Bugai D., Koliabina D. User's manual for NORMALYSA v.2.1. Description of Program Module Libraries, Mathematical Models and Parameters. Facilia AB, Stockholm, 2018. 183 p. DOI: 10.13140/RG.2.2.16037.40168

Antropov, V.M., Bugai, D.A., Dutton, M.C., Gerchikov, M.Y., Kennett, E.J., Ledenev, A.I., Novikov, A.A., Rudko, V., Ziegenhagen, $Y$. Review and analysis of solid long-lived and high level radioactive waste arising at the Chernobyl nuclear power plant and the restricted zone. European Commission, 2001. 294 p. DOI: 10.13140/ RG.2.2.31635.17442

Bugai D.A., Waters R.D., Dzhepo S.P., Skal'skij A.S. Risks from Radionuclide Migration to Groundwater in the Chernobyl 30-km Zone. Health Physics. 1996. Vol. 71, Num. 1. P. 9-18. DOI: 10.1097/00004032-199607000-00002

Bugai D.A., Smith L., Beckie R. Risk-Cost Analysis of Strontium-90 Migration to Water Wells at Chernobyl Nuclear Power Plant. Environmental \& Engineering Geoscience. 1996. Vol. II, No. 2. P. 151-164. DOI: 10.2113/ gseegeosci.II.2.151

Bugai D.A., Skalskiy A.S., Dzhepo S.P. Water protection measures for radioactive groundwater contamination in the Chernobyl exclusion zone. In: Chernobyl - what have learned? The successes and failures to mitigate water contamination over 20 years. Netherlands: Springer Publishers, 2007. P. 203-245. DOI: 10.1007/ 1-4020-5349-5_7

Bugai D., Skalskyy A., Dzhepo S., Kubko Yu., Kashparov V., Van Meir N., Stammose D., Simonucci C., Martin-Garin A. Radionuclide migration at experimental polygon at Red Forest waste site in Chernobyl zone. Pt. 2: Hydrogeological characterization and groundwater transport modeling. Applied Geochemistry. 2012a. Vol. 27, iss. 7. P. 1359-1374. DOI: 10.1016/j.apgeochem.2011.09.028
Bugai D., Tkachenko E., Van Meir N., Simonucci C., Martin-Garin A., Roux C., Le Gal La Salle C., Kubko Yu. Geochemical influence of waste trench no. 22T at Chernobyl Pilot Site at the aquifer: Long-term trends, governing processes, and implications for radionuclide migration. Applied Geochemistry. 2012b. Vol. 27, iss. 7. P. 1320-1338. DOI: 10.1016/j.apgeochem.2011.09.021

Bugai D., Kozak M.W., van Blerk J.J., Avila R. Radiological Safety Assessment of the Zapadnoe Uranium Tailings Facility, Dnieprodzerzhinsk, Ukraine. Paper presented at EU NORM 2 Symposium, Prague, 17-19 June, 2014. DOI: $10.13140 / 2.1 .1575 .5527$

Bugai D., Laptev G., Skalskyy A., Lavrova T., Avila $\boldsymbol{R}$. Analysis of spatial distribution and inventory of radioactivity within the uranium mill tailings impoundment. Ядерна фізика та енергетика. 2015. Т. 16, № 3. C. 254-262. DOI: 10.15407/jnpae2015.03.254

Bugai D., Skalskyy A., Haneke K., Thierfeldt S., Nitzsche O., Tretyak A., Kubko Yu. Groundwater monitoring and modelling of the Vector site for near-surface radioactive waste disposal in the Chernobyl exclusion zone. Ядерна фізика та енергетика. 2017. Т. 18, № 4. C. 382-389. DOI: 10.15407/jnpae2017.04.382

Dewiere L., Bugai D., Grenier C., Kashparov V., Ahamdach N. 90Sr migration to the geo-sphere from a waste burial in the Chernobyl exclusion zone. Journal of Environmental Radioactivity. 2004. Vol. 74, iss. 1-3. P. 139-150. DOI: 10.1016/j.jenvrad.2004.01.019

Dzhepo S.P., Skals'skii A.S. Radioactive contamination of groundwater within the Chernobyl exclusion zone. In: Chernobyl disaster and groundwater. Netherlands: A.A. Balkema Publishers, 2002. P. 25-69.

Freed R., Smith L., Bugai D. The effective source area of $90 \mathrm{Sr}$ for a stream near Chernobyl, Ukraine. Journal of Contaminant Hydrology. 2004. Vol. 71, Iss. 1-4. P. 1-26. DOI: 10.1016/j.jconhyd.2003.07.002

$\boldsymbol{I A E A}$. Technical options for the remediation of contaminated groundwater (IAEA-TECDOC-1088). International Atomic Energy Agency, Vienna, 1999.

IAEA . Mathematical Models for Assessing Remediation of Radioactively Contaminated Sites (TECDOC series report). International Atomic Energy Agency, Vienna, 2018 (in press).

Matoshko A., Bugai D., Dewiere L., Skalskyy A. Sedimentological study of the Chernobyl NPP site to schematize radionuclide migration conditions. Environmental Geology. 2004. Vol. 46, iss. 6-7. P. 820-830. DOI: $10.1007 / \mathrm{s} 00254-004-1067-3$

Molitor N., Drace Z., Bugai D., Sizov A., Haneke K., Thierfeldt S., Nitzsche O., Shapiro Y. Challenges and progress in improving safety and managing radioactive wastes at Chernobyl NPP in the Chernobyl exclusion zone. Проблеми безпеки атомних електростанцій $i$ Чорнобиля. 2017. Вип. 29. С. 35-49. 
Skalskyy O., Bugai D., Voitsekhovitch O., Ryazantsev $\boldsymbol{V}$, Avila R. Groundwater monitoring data and screening radionuclide transport modeling analyses for the uranium mill tailings at the Pridneprovsky Chemical Plant Site (Dneprodzerginsk, Ukraine). In: The New Uranium Mining Boom: Challenge and lessons learned. Springer-Verlag, Berlin, 2011. P. 219-228. DOI: 10.1007/978-3-642-22122-4

\section{References}

Bugai D., Skalskyy A., Dzhepo S., Oskolkov B., 2005. Experimental hydrogeological studies and filtration calculations for the cooling pond of Chernobyl NPP. Bulleten ekologichnogo stanu Zonu vidchuzennya ta zonu bezumovnogo (obovyazkovogo) vidselennya, no. 1 (25), p. 42-56 (in Ukrainian).

Bugai D.A., Fourre E., Jean-Baptiste P., Dapoigny A., Baumier D., Le Gal la Salle C., Lancelot J., Skalskyy A.S., Van Meir N., 2010. Estimation of groundwater exchange at Chernobyl site using the data of the isotope dating and hydrogeological modeling. Geologichnyy zhurnal, no. 4 (333), p. 119-124 (in Russian).

Dzhepo S.P., Sklskyy A.S., Bugai D.A., 1996. Problems of groundwater monitoring in the exclusion zone of Chernobyl NPP. Geologichnyy zhurnal, no. 1-2 (281), p. 107-112 (in Russian).

Skalskyy A.S., Kubko Y.I., 2001. Filtration models of the Chornobyl NPP site. In: Water exchange in hydrogeological structures and Chernobyl catastrophe. Vol. 2. Modeling of water exchange and radionuclide migration in hydrogeology structures. Kiev, p. 462-494 (in Russian).

Saprykin V., Bugai D.A., Skalskyy A.S., Dzhepo S.P., Van Meir N., Kubko Yu., Simounucci C., 2011. The infiltration recharge regime to groundwater at the Chernobyl "Red Forest" site. Zbirnyk naukovyh prats Insytutu Geologichnyh Nauk NAN Ukrainy, vol. 4, p. 141-151 (in Ukrainian).

Shestopalov V.M., Shevchenko O.L., Bugai D.A., Kireev S.I., Nasvit O.I, Proskura M.I., 2006. Perspectives of water protection measures in the Chernobyl exclusion zone. Bulleten ekologichnogo stanu Zonu vidchuzennya ta zonu bezumovnogo (obovyazkovogo) vidselennya, no. 1 (27), p. 62-73 (in Ukrainian).

Avila R., Johansson E., Bugai D., Koliabina D., 2018. User's manual for NORMALYSA v.2.1. Description of Program Module Libraries, Mathematical Models and Parameters. Facilia AB, Stochholm, 183 p. DOI: 10.13140/RG.2.2.16037.40168 (in English).

Antropov, V.M., Bugai, D.A., Dutton, M.C., Gerchikov, M.Y., Kennett, E.J., Ledenev, A.I., Novikov, A.A., Rudko, V., Ziegenhagen, Y., 2001. Review and analysis of solid long-lived and high level radioactive waste arising at the Chernobyl nuclear power plant and the restricted zone. European Commission, 294 p. DOI: 10.13140/ RG.2.2.31635.17442 (in English).
Van Meir N., Bugaï D., Kashparov V. The Experimental Platform in Chernobyl: An international research polygon in the exclusion zone for soil and groundwater contamination. In: Radioactive Particles in the Environment. Springer Science+Business Media B.V., 2009. P. 197-208. DOI: 10.1007/978-90-481-2949-2_13

Bugai D.A., Waters R.D., Dzhepo S.P., Skal'skij A.S., 1996. Risks from Radionuclide Migration to Groundwater in the Chernobyl 30-km Zone. Health Physics, vol. 71, num. 1, p. 9-18. DOI: 10.1097/00004032199607000-00002 (in English).

Bugai D.A., Smith L., Beckie R., 1996. Risk-Cost Analysis of Strontium-90 Migration to Water Wells at Chernobyl Nuclear Power Plant. Environmental \& Engineering Geoscience, vol. II, no. 2, p. 151-164. DOI: 10.2113/gseegeosci.II.2.151 (in English.

Bugai D.A., Skalskiy A.S., Dzhepo S.P., 2007. Water protection measures for radioactive groundwater contamination in the Chernobyl exclusion zone. In: Chernobyl - what have learned? The successes and failures to mitigate water contamination over 20 years. Netherlands: Springer Publishers, p. 203-245. DOI: 10.1007/1-4020-5349-5_7 (in English).

Bugai D., Skalskyy A., Dzhepo S., Kubko Yu., Kashparov V., Van Meir N., Stammose D., Simonucci C., Martin-Garin A., 2012 (a). Radionuclide migration at experimental polygon at Red Forest waste site in Chernobyl zone. Pt 2: Hydrogeological characterization and groundwater transport modeling. Applied Geochemistry, vol. 27, iss. 7, p . 1359-1374. DOI: 10.1016/j.apgeochem. 2011.09.028 (in English).

Bugai D., Tkachenko E., Van Meir N., Simonucci C., Martin-Garin A., Roux C., Le Gal La Salle C., Kubko Yu., 2012 (b). Geochemical influence of waste trench no.22T at Chernobyl Pilot Site at the aquifer: Long-term trends, governing processes, and implications for radionuclide migration. Applied Geochemistry, vol. 27, iss. 7. p. 13201338. DOI: 10.1016/j.apgeochem.2011.09.021(in English).

Bugai D., Kozak M.W., van Blerk J.J., Avila R., 2014. Radiological Safety Assessment of the Zapadnoe Uranium Tailings Facility, Dnieprodzerzhinsk, Ukraine. Paper presented at EU NORM 2 Symposium, Prague, 1719 June. DOI: 10.13140/2.1.1575.5527 (in English).

Bugai D., Laptev G., Skalskyy A., Lavrova T., Avila R., 2015. Analysis of spatial distribution and inventory of radioactivity within the uranium mill tailings impoundment. Nucl. Phys. Atom. Ener., vol. 16, no 3, p. 254262. DOI: 10.15407/jnpae2015.03.254 (in English).

Bugai D., Skalskyy A., Haneke K., Thierfeldt S., Nitzsche O., Tretyak A., Kubko Yu., 2017. Groundwater monitoring and modelling of the Vector site for near-sur- 
Гідрогеологічний моніторинг і математичне моделювання радіоактивного забруднення підземних вод у Чорнобильській зоні відчуження і на уранових обєєктах колишнього Придніпровського хімічного заводу (м. Кам'янське)

face radioactive waste disposal in the Chernobyl exclusion zone. Nucl. Phys. Atom. Ener., vol. 18, no 4, p. 382-389. DOI: 10.15407/jnpae2017.04.382 (in English).

Dewiere L., Bugai D., Grenier C., Kashparov V., Ahamdach N., 2004. 90Sr migration to the geo-sphere from a waste burial in the Chernobyl exclusion zone. Journal of Environmental Radioactivity, vol. 74, iss. 1-3, p. 139-150. DOI: 10.1016/j.jenvrad.2004.01.019 (in English).

Dzhepo S.P., Skals'skii A.S., 2002. Radioactive contamination of groundwater within the Chernobyl exclusion zone. In: Chernobyl disaster and groundwater. Netherlands: A.A. Balkema Publishers, p. 25-69 (in English).

Freed R., Smith L., Bugai D., 2004. The effective source area of $90 \mathrm{Sr}$ for a stream near Chernobyl, Ukraine. Journal of Contaminant Hydrology, vol. 71, iss. 1-4, p. 1-26. DOI: 10.1016/j.jconhyd.2003.07.002 (in English).

IAEA., 1999. Technical options for the remediation of contaminated groundwater (IAEA-TECDOC-1088). International Atomic Energy Agency, Vienna (in English),

$\boldsymbol{I A E A}$., (in press). Mathematical Models for Assessing Remediation of Radioactively Contaminated Sites (TECDOC series report). International Atomic Energy Agency, Vienna (in English).
Matoshko A., Bugai D., Dewiere L., Skalskyy A., 2004. Sedimentological study of the Chernobyl NPP site to schematize radionuclide migration conditions. Environmental Geology, vol. 46, iss. 6-7, p. 820-830. DOI: 10.1007/s00254-004-1067-3 (in English).

Molitor N., Drace Z., Bugai D., Sizov A., Haneke K., Thierfeldt S., Nitzsche O., Shapiro Y., 2017. Challenges and progress in improving safety and managing radioactive wastes at Chernobyl NPP in the Chernobyl exclusion zone. In: Problems of nuclear power plants' safety and of Chornobyl, iss. 29, p. 35-49 (in English).

Skalskyy O., Bugai D., Voitsekhovitch O., Ryazantsev V., Avila R., 2011. Groundwater monitoring data and screening radionuclide transport modeling analyses for the uranium mill tailings at the Pridneprovsky Chemical Plant Site (Dneprodzerginsk, Ukraine). In: The New Uranium Mining Boom: Challenge and lessons learned. Springer-Verlag, Berlin, p. 219-228. DOI: 10.1007/9783-642-22122-4 (in English).

Van Meir N., Bugaï D., Kashparov V., 2009. The Experimental Platform in Chernobyl: An international research polygon in the exclusion zone for soil and groundwater contamination. In: Radioactive Particles in the Environment. Springer Science+Business Media B.V., p. 197-208. DOI: 10.1007/978-90-481-2949-2_13 (in English).

Стаття надійшла 25.06.2018 